\title{
SUSTAINABLE TOURISM - SENSIBLE TOURISM
}

\author{
TURYSTYKA ZRÓWNOWAŻONA - ROZTROPNY TURYZM
}

\begin{abstract}
The article presents the issues related to travel and tourism, the development of this branch of service, and attempts to create alternative solutions to reduce this phenomenon's dysfunctions. The introduction outlines the nineteenth century beginnings of tourism on the British Isles, including the setup of the first travel agency and the effects of increasing number of participants of mass tourism. The second section discusses the evolution from traveller to the tourist consumer of the commercial offer and social and environmental impacts of these changes. The third part presents the attempts to create alternatives to mass tourism with the adaptation of the rules resulting from the concept of sustainable development, and stressed the need for pro-environmental education.
\end{abstract}

Keywords: tourism, sustainable tourism, travel, responsible tourism

\section{Introduction}

Tourism is often described as a phenomenon destructive to the environment, especially the nature. This belief is further instilled by media who broadcast the conflicts resulting from mass tourism investments. An example would be construction of ski centres, from the 1920s - an example being the cable car on Kasprowy [1] to the present day - a ski resort on the slopes of Pilsko mountain [2]. The subject of protecting the natural environment is not new and, noticed in the mid-nineteenth century, resulted in the creation of protected areas and organizations whose aim, next to adventure and sports, was exploring especially attractive regions. An exclusive Alpine Club was created in 1857 in an industrial England. It was the first club bringing together people educated in public schools and colleges who, through their work conditions enjoyed long summer holiday [3]. The advent of time off work in this social group has offered the possibility of active summer holiday. Emerging British middle class would explore attractions of Scotland and Wales and then they would move on to exploring other areas of interest. Exploration of Alps, due to their relative proximity, became a stimulus for further, more advance travel. The interest in this way of spending spare time has become increasingly common. The answer was the creation of the first travel agency Thomas Cook in 1841. Initially, Cook organized the occasional group railway trips, and then as of 1864 offered trips to the continent. Soon, "Thomas Cook and Son", a family enterprise, offered organized group trips to India. Today, Thomas Cook

\footnotetext{
${ }^{1}$ Institute of Environmental Protection and Engineering, University of Bielsko-Biala, ul. Willowa 2, 43-309 Bielsko-Biała, Poland, phone +48 33827 91 39, email: wzyzak@ath.bielsko.pl
} 
Group plc is one of the biggest tourist organizations. Commercialization of tourist services and the rapidly growing demand for tourist services resulted in a creation of a dynamic business sector that offers not only organized transport arrangements but also hotel accommodation with more and more attractive offers of spending time. In the mid-twentieth century the tourism industry has taken on such great proportions, that it became apparent that some measures had to be put in place to limit the environmental damage resulting from mass tourism, particularly in areas of exceptional beauty or scientific value. As well as nature, the local communities required protection and preservation.

Subsequently, a tourist as a consumer of mass commercial product, became the subject of criticism. Furthermore, travel which was once a noble activity associated with educated individuals (an example being the "Grand Tour" enjoyed by aristocracy or people of substantial wealth) became frown upon.

\section{Traveller vs tourist}

The development of increasingly accessible means of transport, easier access to information on places and regions of interest, and the rising wealth of the inhabitants of developed countries have caused a sharp increase in the number of tours. The World Tourism Organization (UNWTO) estimated that in 1950 around 25 million people travelled internationally and in 1990 this figure rose to nearly 520 million. Up to 1980 the international traffic doubled every decade [4].

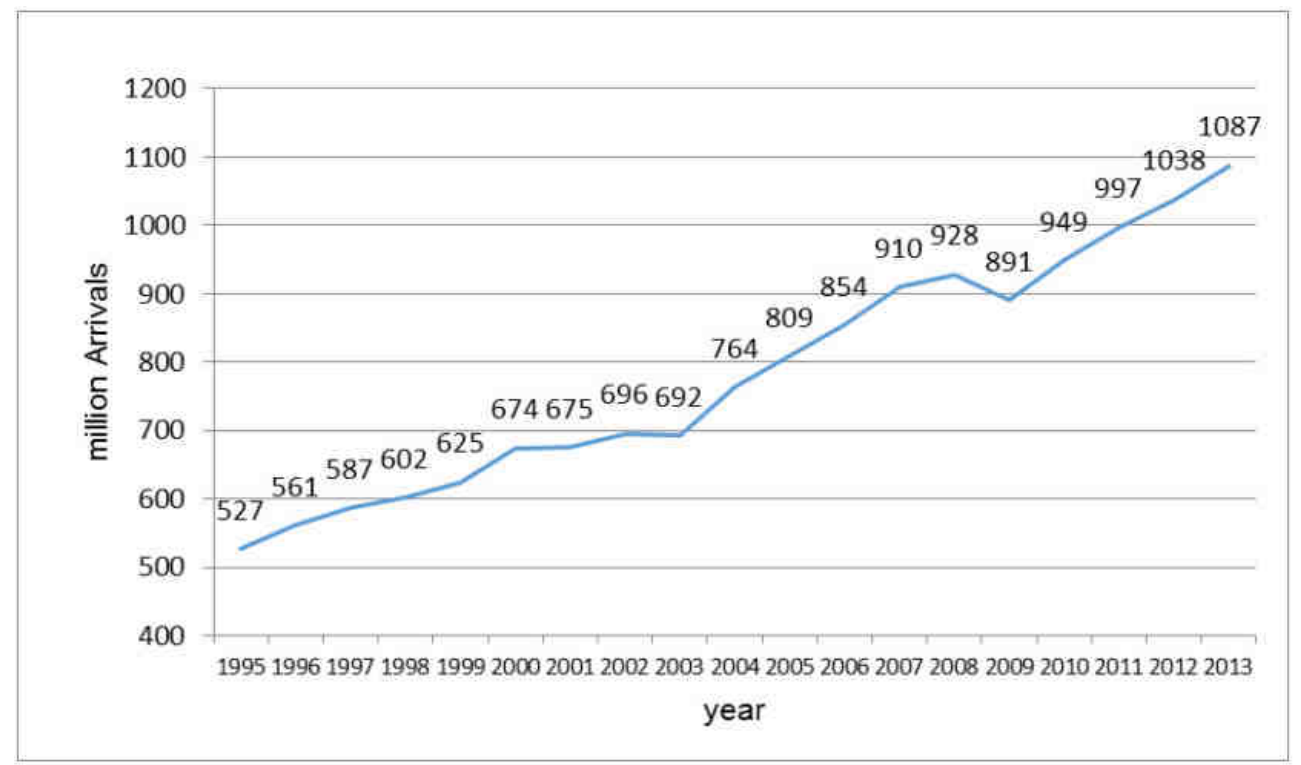

Fig. 1. International tourist arrivals 1995-2013 [5]

In the following decades, the increase in the number of people who travelled internationally slowed down. However, the turn of centuries saw double increase of the international tourists within 18 years (Fig. 1). An average tourist became the product of the 
business designed to generate profit. Trips were increasingly devoid of cognitive value and reduced to stay in places that allow escape from everyday reality. Today's package holiday tourist ceased to be a traveller, and has become a consumer of the commercial offer. Once the purpose of travelling which was getting to know the culture and nature of the chosen destination, was replaced by passive recreation in relatively high standards of mass transport, accommodation, culinary offerings and leisure. Paul Theroux satirically defined the difference between the tourist and the traveller: "Tourists don't know where they've been, travellers don't know where they're going." It seems that this statement accurately describes the reality of today's mass tourism.

The evolution of tourism was equally well captured by Hans Joachim Knebel [6]. According to him the traveling has changed as follows:

- from family travel to individual travel,

- from contacts with locals to contacts between tourists,

- from travelling communities to travel agencies,

- from travelling as a way of striving for freedom to travel as voluntary slavery,

- from the unscheduled to the rigidly organized,

- from the Alpine club to the moto-club and camping-club,

- from expression individual tastes to submitting to the dictates of fashion,

- from understanding to stereotyping,

- from communication and dialogue to receiving information,

- from romantic feelings to feelings programmed,

- from walks to shopping,

- from experience to photographic images,

- from letters to postcards,

- from fourth grade travel to travel first class,

- from art to kitsch,

- $\quad$ and finally, from a dormitory to a hotel.

As a result, we distinguish between a traveller and a tourist who was reduced to a consumer of a mass tourism. Growing demand resulted in a need for more and more new destinations in attractive locations. Travel agents wanted to maximize the profit from mass tourism cater for an ever increasing level of consumption, which in turn led to increasing strain on the environment and its resources. Consequently, this resulted in devastation of natural resources. A measure of this was an amount of raw materials needed for the construction of infrastructure, energy to maintain comfort of the hotel and its surrounding areas, entertainment and catering, and consequently the amount of waste generated. At the Congress of the World Tourism Organisation (WTO) held in Manila in 1980 which considered the negative impacts of tourism, the delegates concluded that mass tourism brings more harm than benefits. The negative effects of mass tourism were observed in developing countries, which were opening new markets for tourism services. These phenomena also occurred in Europe and the Northern Africa. In Tunisia, Morocco and even in Greece and Spain investors from Germany, Britain or France were the main group benefiting from the seaside hotels. The qualified staff and the majority of customers would also come from the developed countries. However, the negative social and environmental costs were footed by the reception countries. Among the most common negative effects on the natural environment and society are: 
- Changes in the landscape - the construction of hotels and associated entertainment and catering infrastructure, expansion of the transport network and construction of car parks, deforestation around ski centres, development of resorts/loges and viewpoints and hiking trails;

- Increased consumption of resources - related to construction of buildings used seasonally and the accompanying infrastructure, increased demand for water and energy - heat in the mountains, electricity in coastal areas;

- Pollution of water, air and soil - resulting from concentration of tourist services in time and in places;

- Stimulating undesirable effects - erosion of trails, avalanches, landslides;

- Increased production of waste - within accommodation areas and outdoors;

- Reducing biodiversity - the destruction of protected plants, the spread of monocultures, eg Golf courses, lawns, recreational areas, invasive plants introduced to create more attractive environment;

- Intensification of synanthropisation of animals - through frequent presence of people in ecosystems and through leaving food;

- Increase in negative social effects - the severity of crime, prostitution, drug trafficking;

- Economical dissection of local communities;

- The commercialization of culture, religion and art.

This way perceived mass tourism became distant from the concept of a traveller, who is sensitive to the needs of the local environment of the travel destination.

\section{Sustainable tourism}

Popularisation of travel in the mid-twentieth century resulted in the need for a new approach to tourism. Concepts of alternative tourism emerged. The approach to tourism was divided into hard tourism - associated with mass tourism and soft tourism - friendly towards a local society and natural environment. In 1965 Hetzer [7] presented the concept of a responsible tourism, in which he proposed:

- minimizing human intervention in the natural environment;

- $\quad$ respect for cultural diversity of the visited places;

- maximizing the participation of local communities in tourist services and, consequently;

- $\quad$ increase in satisfaction of both residents and tourists.

There are also other, more environmentally friendly proposals for spending time 'away from home': ecotourism, cognitive / thematic tourism (geotourism, cultural tourism, etc.). According to these types of qualified tourism, the participants should have a range of knowledge and skills and be aware of the consequences of their actions and their impact on the environment. These assumptions, however, were questioned and Butler [8] in his article entitled 'Alternative Tourism. Wishful thinking or Trojan horse' argued that alternative forms of travel to mass tourism forms of travel do not solve the issue of the dysfunctionality of tourism. However, in light of the growing demand for tourist services the countries which have recognized tourism as an important element of development introduced solutions which were to minimize negative impact of mass tourism. One example of the structural solutions was the Swiss model (Fig. 2), which adopted approach that assumed three areas of equal importance: social, economic and natural. 


\section{Legal norms in tourism + investment in tourism}

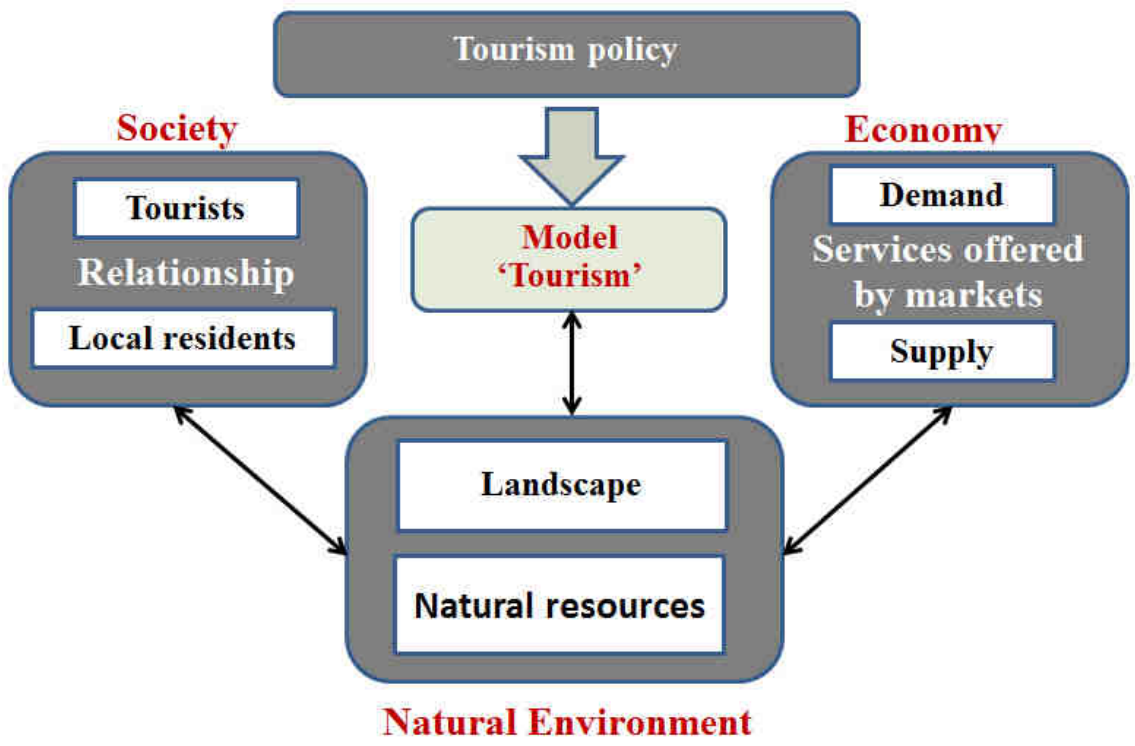

Fig. 2. Swiss model of tourism development by Beratende Kommission für Fremdenverkehr des Bundesrates: Das Schweizerische Tourismuskonzept (1979), Bern [9]

Selected documents regarding sustainable tourism [10]

\begin{tabular}{|c|c|c|}
\hline Document title & Prepared by & $\begin{array}{c}\text { Year and place } \\
\text { of publication }\end{array}$ \\
\hline Charter for Sustainable Tourism & $\begin{array}{c}\text { World Conference for Sustainable } \\
\text { Tourism }\end{array}$ & $\begin{array}{c}1995, \text { Lanzarote, Canary } \\
\text { Islands }\end{array}$ \\
\hline $\begin{array}{c}\text { Agenda 21 for the Travel and Tourism } \\
\text { Industry; Towards Environmentally } \\
\text { Sustainable Development }\end{array}$ & WTTC, UN WTO, Earth Council & 1995, Madrid \\
\hline $\begin{array}{c}\text { Berlin Declaration on Biological Diversity } \\
\text { and Sustainable Tourism }\end{array}$ & $\begin{array}{c}\text { International Conference } \\
\text { of Environmental Ministers } \\
\text { on Biodiversity and Tourism }\end{array}$ & 1997, Berlin \\
\hline Global Codes of Ethics for Tourism & UN WTO & 1999, Santiago de Chile \\
\hline $\begin{array}{c}\text { Sustainable Development of Tourism. } \\
\text { Conceptual Definitions }\end{array}$ & UN WTO & 2004, Madrid \\
\hline Global Sustainable Tourism Criteria & $\begin{array}{c}\text { World Conservation Congress } \\
\text { (Rainforest Alliance, UNEP, UN WTO }\end{array}$ & 2008, Barcelona \\
\hline
\end{tabular}

The above quoted publications preceded the publication of the Brundtland report, entitled "For Our Common Future" [11], which formulated the construct of Sustainable Development for the first time. Similar concepts were analysed earlier, one example being the harmonious development and eco-development [12], however, the rank of the UN Commission led by Gro Harlem Brundtland, and further development of the sustainable 
development idea made it a concept generally known and widely referred to. The term sustainable is being used when describing the tourism activities/business, which should be socially desirable, economically justified and executed respecting natural resources. Sustainable tourism has received extensive theoretical foundation in the form of global reports created as a result of international cooperation (Table 1), which sets out the principles, priorities and criteria to guide the further development of tourism including corrected mass tourism $[10,13]$.

Having considered the above discussion on the negative impact of the mass tourism, we would like to pose a question if the mass tourism can be less oppressive? We need to assume that the every living organism interacts with its ecosystem, and as a result of this interaction there are changes to the organism and the ecosystem. Secondly, we need to assume that we could put in place at least some of the ideas included in the above quoted publications on the ways of minimizing negative impact of the mass tourism. Should both assumptions come true we could answer that the negative effect of the mass tourism could be mitigated to a certain degree. In other words - the mass tourism could adopt a 'human face' [14]. Matuszyk argued that the very fact of movement implicate ability to stop. This further allows adjusting in order to better co-operate with the surroundings. In fact, this is the very essence of the tourism. Aristotle argued that one need to get in touch with reality in order to get to know it. A mind needs to connect with the world through the senses. The knowledge starts with observation [15]. Sensitive and sensible interaction with nature may be a starting point of learning. Research conducted by Mroczka [16] in Babiogorski National Park demonstrated that the main reason for visiting the park was the outdoor activities and the need for contact with nature. The most frequently indicated reason for the visit was the beauty of the landscape ( $85 \%$ of respondents) and admiration for the orderly structure of nature (over 38\%). The respondents did not expect comfort on the trail and expressed support for the development of minimally invasive forms of tourism in the national park. In conclusion - the respondents represented a model of a tourist who is respectful of their surroundings.

Analysis of the risks associated with tourism in the selected areas of Natura 2000 [17] is also optimistic. The authors investigated the threats to the natural environment by analysing records in Standard Data Forms conducted for Natura 2000 and compared them to the results of the anthropopression assessment. The authors concluded that the current level of development of tourism and recreation on the Natura 2000 and surrounding areas does not materially threaten qualities of these areas (in general). In twelve of the 56 areas studied any negative effects of tourism and recreation were almost unobservable within the area and its surroundings. In summary, the authors found that having less harmful forms of tourism in the Natura 2000 area and its surroundings is not a danger to them.

\section{Conclusions}

The positive aspects of tourism, signalled in the quoted publications, do not prove the absence of the negative effects of tourism. However, the use of methods enabling a reduction of the oppressiveness of tourism creates great opportunities for directing such a dynamic development of this industry. Conduct a proper valuation of reception areas and a selection, based on this valuation, of areas of limited use or even restrictive protection, would greatly helped to protect sensitive areas. Zoning space with rational planning the 
provision and management of buffer areas or transition (like in $\mathrm{MaB}$ ) can be an effective form of prevention. Professionally designed strategies for tourism development with a selection and activation of areas of alternative and fair evaluations with modern monitoring can restore the human face of this form of spending time. And it seems the most important action - pro-environment education: less emotionally-protective, and more grounded in classical understanding of ecology by Ernst Haeckel.

At this point it would seem justified, to recall again Aristotle, who in search of truth suggests the use of both: the speculative and practical intelligence. For both aspects: the theory and practice of seeking the truth Aristotle recommends (Nicomachean Ethics, VI) application of prudence, which stems from four intellectual virtues: episteme (science), techne (technical skill, creativity), nous (thinking) and sophia (wisdom). For the purpose of analysis of tourism and its effects on the environment, any configuration of these intellectual virtues is desirable.

\section{References}

[1] Skawiński P. Oddziaływanie człowieka na przyrodę kopuły Kasprowego Wierchu oraz Doliny Goryczkowej w Tatrach. (Human impact on nature of Kasprowy Wierch and Goryczkowa Valley in the Tatra Mountains). [in:] Ochrona Tatr w obliczu zagrożeń. Cichocki W, editor. Zakopane: Wyd Muzeum Tatrzańskiego; 1993:197-226.

[2] Mika M. Environmental impact of tourism development in reception areas in Poland and methods of controlling them. Prace Geograf. 2003;111:129-142. http://www.pg.geo.uj.edu.pl/documents/ 3189230/4676042/2003_111_129-142.pdf.

[3] Pilkington Ch. Fifty years of the Alpine Club. Alpine J. 1909;24:15-29. http://pahar.in/mountains/ 1909-the-alpine-journal-vol-24-s-pdf.

[4] Durydiwka M. Ruch turystyczny - z centrum ku peryferiom. (Tourist movement - from centre to peripheries). Prace Studia Geograf. 2009;42:59-71. http://wgsr.uw.edu.pl/uploads/ f_biblioteka/PIS/42/Durydiwka.pdf.

[5] Tourism Highlights 2014 Edition, Madrid: UN WTO; 2015. http:unwto_annual_report_2014.pdf.

[6] Knebel HJ. Soziologische Strukturwandlungen im Modernen Tourismus. Stuttgart: Ferdinand Enke; 1960.

[7] Hetzer W. Environment, tourism, culture. 1965. Links July, 1-3.

[8] Butler RW. Alternative tourism: pious hope or Trojan horse? J Travel Res. 1990;28(3):40-45. DOI: 10.1177/004728759002800310.

[9] Müller H. Tourismus und Ökologie. München: Oldenburg Verlag; 2007.

[10] Butowski L. Sustainable Tourism - A Model Approach. In: Kasimoglu M, editor. Visions for Global Tourism Industry - Creating and Sustaining Competitive Strategies. Rijeka: In Tech; 2012:3-20.

[11] Our Common Future. Report of the World Commission on Environment and Development: 1987. www.un-documents.net/our-common-future.pdf.

[12] Sachs I. Stratégies de l'écodéveloppement. (Strategies of Ecodevelopment). Éditions ouvrières; Paris: Les Éditions ouvrières; 1980.

[13] Sharpley R. Tourism and sustainable development: Exploring the theoretical divide. J Sustain Tourism. 2000;8(1):1-19. DOI: 10.1080/09669580008667346.

[14] Matuszyk A. Turystyka z ludzką twarzą, czyli o wartościach turystyki aktywnej. (Tourism with a human face, or about values of active tourism). In: Żywiecczyzna-Turystyka-Środowisko. Zyzak W, editor. TNŻ Biblioteka Żywiecka. 2008;10:113-122.

[15] Aristotle. Nicomachean Ethics. Translated by W.D. Ross. Batoche Books. Kitchener. 1999:91-105. http://socserv2.socsci.mcmaster.ca/econ/ugcm/3113/aristotle/Ethics.pdf.

[16] Mroczka A. Wybrane aspekty atrakcyjności turystycznej Babiogórskiego Parku Narodowego w świetle badan ankietowych. (Selected aspects of the touristic attractiveness of the Babiogórski National Park in the light of the questionnaire scientific research). Mat. Konf. Rozwój turystyki kulturowej i przyrodniczej na pograniczu polsko-słowackim. Nowy Targ: PPWSZ; 2012:87-92. http://www.konferencja.ppwsz.edu.pl/ _pliki/12-mroczka,b660f.pdf. 
[17] Witkowski Z, Mroczka A, Ciapała S. Zagrożenia związane z turystyką i rekreacją na obszarach Natura 2000 w regionie alpejskim w świetle Standardowych Formularzy Danych. (Threats associated with tourism and recreation in Natura 2000 areas in alpine region in the light of Standard Data Forms). Folia Turistica. 2012;26:91-105. http://www.folia-turistica.pl/attachments/article/402/FT_26_2012.pdf.

\title{
TURYSTYKA ZRÓWNOWAŻONA - ROZTROPNY TURYZM
}

Instytut Ochrony i Inżynierii Środowiska, Akademia Techniczno-Humanistyczna w Bielsku-Białej

\begin{abstract}
Abstrakt: W artykule przedstawiono problemy związane z podróżami oraz turystyką, rozwojem tej gałęzi usług oraz próby tworzenia alternatywnych rozwiązań ograniczających dysfunkcyjność tego zjawiska. We wstępie zarysowano XIX-wieczne początki turyzmu na Wyspach Brytyjskich z powstaniem pierwszego biura podróży oraz skutki wzrastającej liczby uczestników turystyki masowej. Następnie omówiono ewolucję: od podróżnika do konsumenta turystycznej oferty komercyjnej oraz skutki społeczne i środowiskowe tych przemian. W części trzeciej przedstawiono próby tworzenia rozwiązań alternatywnych do turystyki masowej z adaptacją zasad wynikających z koncepcji rozwoju zrównoważonego oraz wskazano na konieczność edukacji prośrodowiskowej.
\end{abstract}

Słowa kluczowe: turyzm, turystyka zrównoważona, podróże, turystyka odpowiedzialna 